\title{
14
}

\section{Disciplining Artificial Intelligence Policies}

\section{World Trade Organization Law as a Sword and a Shield}

\author{
Kelly K. Shang and Rachel R. Du*
}

\section{INTRODUCTION}

The rapid development of artificial intelligence (AI) technology has brought to humanity benefits and challenges. The potential risk for AI technology to be used for controversial purposes, and the need for the international community to develop disciplines on the use of AI, are noticed by many. For example, in May 2019, the Secretary-General of the United Nations (UN) denounced AI-powered "lethal autonomous weapons" as "politically unacceptable [and] morally repugnant", and called for such weapons to be "prohibited by international law". 'In November 2019, a US Congressional Research Service (CRS) report identified the risks of AI applications being used in surveillance and reconnaissance applications, in autonomous weapon systems, ${ }^{2}$ or to serve "dual-use" purposes. ${ }^{3}$ In February 2020, a European Union (EU) White Paper on AI identified that the use of AI could affect, inter alia, "fundamental rights, including the rights to freedom of expression[,] nondiscrimination ... [and the] protection of personal data". ${ }^{4}$

In addition to national security or fundamental rights concerns, the theme of "fair competition" in developing of AI products causes further controversies. For

An earlier version of this chapter received the Young Scholar Award from the Asian International Economic Law Network (AIELN) in 2019. The authors give thanks to Peter Van den Bossche, ChingFu Lin, Shin-yi Peng, Thomas Streinz and Rolf H. Weber for their comments.

1 "Secretary-General's Message for Third Artificial Intelligence for Good Summit" (United Nations, 28 May 2019), https://perma.cc/B5HW-RV5U (hereinafter SG Message for AI).

2 Congressional Research Service (CRS), "Artificial Intelligence and National Security" (2019), https:// perma.cc/B5 TC-J $2 U_{9}<$ int_i, at 10.

3 Ibid., at 3. For discussions on the dual use of AI technologies, see M Brundage et al., "The Malicious Use of Artificial Intelligence: Forecasting, Prevention, and Mitigation" (2018), https://perma.cc/Z2KJ$\mathrm{WYJ}_{3}$, at 79 .

4 "Commission White Paper on Artificial Intelligence: A European Approach to Excellence and Trust" (2020), https://perma.cc/24AE-UJGM, at 10; see also J Purshouse and L Campbell, "Privacy, Crime Control and Police Use of Automated Facial Recognition Technology" (2019) 3 Criminal Law Review 188 (arguing that England and Wales should adopt a "narrower and more prescribed legal framework" in their use of facial recognition to comply with international law). 
example, the 2019 CRS report on AI, while alluding to China's Military-Civil Fusion policy, cautioned that some "US competitors may have fewer moral, legal, or ethical qualms" about the development of certain AI applications.

Suggestions and proposals have been made by entities including the EU, the G-20 ${ }^{5}$ and the Organisation for Economic Co-operation and Development $(\mathrm{OECD})^{6}$ for the international community to develop new disciplines in regulating the development and use of $\mathrm{AI}$ technologies. ${ }^{7}$ However, no binding rules seem to have been reached on an international level at this stage. ${ }^{8}$

In certain areas, states are bound by their existing international law obligations when shaping their AI policies. For instance, AI policies concerning facerecognition cameras need to comply with the various international obligations prescribed in (inter alia) the International Covenant on Civil and Political Rights (ICCPR). Similarly, AI policies seeking to undermine the national security of other states also must comply with (inter alia) the principle of non-intervention in internal affairs as a general principle of international law.

At present, the primary deterrence for trade powers from abusing AI technology is perhaps the unilateral economic sanctions 9 taken by states in an individual or collective manner (AI sanctions). Occasionally, such sanctions are criticised for breaching the sanctioners' commitments under the World Trade Organization (WTO). ${ }^{10}$

This chapter aims to examine the relationship between the current WTO law and the controversial use of AI policies. In particular, it examines the following questions: (a) whether WTO law can sufficiently regulate "data-sharing" policies that seek to promote the development of AI technologies; and (b) whether WTO law can justify sanctions against other WTO members for their controversial use of AI technologies, especially those seeking to undermine fundamental rights or national security.

A preliminary comment needs to be made at this stage: this chapter does not seek to set out legal or ethical "tests" to judge what kind of AI policies are "controversial",

5 "G20 Ministerial Statement on Trade and Digital Economy" (2019), https://perma.cc/WCC2-J32 $\mathrm{P}$.

6 OECD, "Recommendation of the Council on Artificial Intelligence" (2019) OECD/LEGAL/o449, https://perma.cc/DV 5 K-B6A3.

7 See M Risse, "Human Rights and Artificial Intelligence: An Urgently Needed Agenda" (2018), https:// perma.cc/SX67-78YE; and Beijing Academy of Artificial Intelligence, "Beijing AI Principles" (2019), https://perma.cc/GB28-8J6A. For comments concerning the "Beijing Principles", see W Knight, "Why Does Beijing Suddenly Care about AI Ethics?” (MIT Technology Review, 31 May 2019), https://perma.cc $13 \mathrm{KDH}-\mathrm{QHJJ}$.

8 See J Thornhill, "Formulating Values for AI Is Hard When Humans Do Not Agree" (Financial Times, 22 July 2019), https://perma.cc/5XAG-JQXC.

9 Such instruments are commonly referred to as "autonomous sanctions" by Australia and the United States. Shaw convincingly argued that non-military sanctions are "legitimate method[s] of showing displeasure" and do not contravene general public international law. MN Shaw, International Law (8th ed., Cambridge, Cambridge University Press, 2017), 859.

10 See subsection C in Section II for detailed examples. 
nor does it seek to pronounce any specific AI policy as such. No universal legal or ethical guideline concerning the development or use of AI seems to have been reached so far, possibly because of the significant cultural and ideological differences among major AI powers.

The structure of this chapter is as follows. Section II reviews major types of controversial AI policies among the trade powers, and provides an overview of the international responses to such controversial uses. Section III considers whether current WTO disciplines can sufficiently regulate "data-sharing" policies for the development of AI technologies. Section IV turns to examine whether WTO law can justify sanctions against other WTO members for their controversial use of AI technologies. Section V summarises and concludes this chapter.

\section{CURRENT USE AND INTERNATIONAL RESPONSE TO CONTROVERSIAL}

\section{ARTIFICIAL INTELLIGENCE POLICIES}

\section{A Major Controversies Concerning Artificial Intelligence Policies}

Major controversies among trade powers on AI policies are manifested in two ways. The first way concerns the development of AI systems. Specifically, a country may use state power to collect personal data and "feed" them to their AI industry, or alternatively encourage the "shared use" of personal data across government and private sectors. ${ }^{11}$ For example, China's "military-civil fusion" policy seeks to promote (if not require) data-sharing between its commercial companies and its government, ${ }^{12}$ apparently with the aim of "creating [at a lower cost] the large databases on which AI systems train". ${ }^{33}$

The second way concerns the use of AI systems. Specifically, AI policies can be used to undermine fundamental rights, either within the WTO member in question itself or within other members, ${ }^{14}$ in order to pursue such policy objectives including domestic surveillance, legal enforcement or international espionage. Further, AI policies can be pursued to undermine the national security of other members, including espionage and manipulation of another member's domestic politics such as elections. ${ }^{15}$

${ }^{11}$ See Notice of the State Council on Issuing the Development Plan on the New Generation of Artificial Intelligence (PRC), which sets out a strategy of "civil-military integration" in the PRC's AI development plan, and seeks to promote the "sharing and joint use" of AI innovation platforms including data resources, and cloud service platform etc.

12 See CRS, note 2 above, at 21. See also "Military-Civil Fusion and the People's Republic of China", https://perma.cc/4DMR-B2K9.

13 CRS, note 2 above, at 20.

14 See M Wang, China's Algorithms of Repression: Reverse Engineering a Xinjiang Police Mass Surveillance App (New York, Human Rights Watch, 2019); Purshouse and Campbell, note 4 above.

15 See A Polyakova, "Weapons of the Weak: Russia and AI-Driven Asymmetric Warfare" (Brookings, November 2001), https://perma.cc/CG8V-U4 QA (arguing that Russian institutions interfered with the 2016 US presidential elections by AI-powered propaganda), and “The Propaganda Tools Used by 


\section{B International Response to Predatory Artificial Intelligence Policies}

The potential risks of AI policies have, in recent years, attracted increasing international attention. For example, in 2019, the UN Secretary-General called for international collaborations to "address the risks [of AI and] to develop the frameworks and systems that enable responsible innovation". ${ }^{16}$

In achieving such a goal, the Secretary-General called for an international regulatory system to be developed for the "responsible innovation" on AI, with "binding laws and instruments" in place. ${ }^{17}$ In addition to this suggested path, WTO members may also decide to take collective or individual countermeasures as a deterrence against other states which, under their judgement, maintain problematic AI policies.

In practice, the primary deterrence against problematic $\mathrm{AI}$ policies appears to be unilateral economic sanctions. Such uses are piecemeal: as an example of AI sanctions targeted against human rights abuses, consider the USA's imposition of Magnitsky sanctions in July 2020 against certain Chinese government individuals and entities that (according to the USA) used AI platforms "for racial profiling" and "data-driven surveillance" against ethnic minorities. ${ }^{18}$ Also, consider the call in June 2020 by the European Parliament for "the EU ... and the international community ... [to impose] appropriate export control mechanisms including cyber surveillance items to deny China, and in particular Hong Kong, access to technologies used to violate basic rights". ${ }^{19}$

Sanctions may also be used to restrict AI-powered computer programs that act as surveillance and propaganda instruments for foreign countries. The US Secretary of State's statement in July 2020 for a possible ban on China's TikTok app, which apparently uses an AI-powered algorithm for "censorship and surveillance", can serve as an example. ${ }^{20}$

Russians to Influence the 2016 Election" (New York Times, 16 February 2018), https://perma.cc/CP 7 C$\mathrm{BV}_{4} \mathrm{~L}$.

16 SG Message for AI, note 1 above.

17 Ibid.

18 "Treasury Sanctions Chinese Entity and Officials Pursuant to Global Magnitsky Human Rights Accountability Act" (U.S. Department of the Treasury, 9 July 2020), https://perma.cc/8ZFE-9XK8. For background information, see "Xinjiang Supply Chain Business Advisory" (2020), https://perma.cc /G53R-D66W. Also see Wang, note 14 above.

19 "European Parliament Resolution on the PRC National Security Law for Hong Kong and the Need for the EU to Defend Hong Kong's High Degree of Autonomy" (2020) 2020/2665, at para. 13. For an earlier resolution, see "European Parliament Resolution of 18 July 2019 on the Situation in Hong Kong" (2019) 2019/2732(RSP), at para. 11.

2o "Secretary Michael R. Pompeo with Laura Ingraham of Fox News" (US Department of State, 6 July 2020), https://perma.cc/HLNg-UVUN; F Ryan et al., "Mapping More of China's Technology Giants: AI and Surveillance" (2019) ASPI Issues Paper Report No. 24 (proposing that TikTok is a "vector for censorship and surveillance", empowered by an AI-powered algorithm). 


\section{Sanctions on Artificial Intelligence-Powered Goods/Services and World Trade Organization Law}

From the perspective of international trade law, it appears that AI sanctions can take at least two forms. First, a sanction may take the form of an import restriction, possibly with the aim of preventing the sanctionee's problematic AI technology from being in contact with the sanctioner: the USA's proposed restriction against TikTok being installed on US mobile phones could be an example.

Second, a sanction may also take the form of an export barrier: examples of these measures include the USA's restriction against China over its use of AI for "racial profiling" and "data-driven surveillance", and the European Parliament's proposed sanctions against China and Hong Kong. Specifically, such sanctions can either be used aggressively with the aim of terminating a (perceived) predatory AI policy (such as by cutting off the "raw materials" supply), or defensively as a measure to protect the sentiment of the invoking member's own citizens as "abetters" of the problematic policy in question.

Sanctionees frequently argue that the sanctions they encounter are against WTO rules. ${ }^{21}$ Some scholars seem to hold similar views: Lester and Zhu questioned the WTO consistency of the Trump administration's expansive use of trade barriers on national security grounds. ${ }^{22}$ In the context of trade restrictions to address data security or foreign influence concerns, Zhou and Kong argued that Australia's Huawei ban is "unjustifiable under the WTO". ${ }^{23}$ Similarly, Voon argued that Australia would "face significant challenges" if China were to lodge a WTO complaint against Australia's Huawei ban. ${ }^{24}$ While the Huawei controversies primarily involve national security concerns on $5 \mathrm{G}$ networks, it would seem that similar arguments could be advanced against sanctions on AI products that threaten national security.

Can the trade liberalisation commitments undertaken by WTO members restrict their ability to impose AI sanctions to safeguard fundamental rights or national security? Indeed, it would seem that if a member were to impose "sanctions" in the forms of import or export restrictions on goods or services, it might prima facie contravene its obligations to offer most favoured nation (MFN) treatment (General Agreement on Tariffs and Trade (GATT) Art. I, General Agreement on Trade in Services (GATS) Art. II) and national treatment (NT)

${ }^{21}$ See "China: India's Ban on Chinese Apps May Violate WTO Rules" (China Global Television Network, 1 July 2020), https://perma.cc/7EEA-HVE8 (reporting that Ji Rong, spokesperson for the Chinese embassy in New Delhi, said that India's ban of certain Chinese mobile apps including TikTok and WeChat "runs against fair and transparent procedure requirements, abuses national security exceptions and (is suspected of) violating WTO rules").

22 S Lester and H Zhu, "A Proposal for 'Rebalancing' to Deal with 'National Security' Trade Restrictions" (2019) 42 Fordham International Law Journal 1451.

23 W Zhou and Q Kong, "Why Australia's Huawei Ban Is Unjustifiable under WTO" (China Global Television Network, 29 April 2019), https://perma.cc/A4DW-3 YB5.

24 J Fernyhough, "Australia's Huawei ban on shaky ground at WTO" (Australian Financial Review, 15 April 2019), https://perma.cc/EH2L-U3NT 
(GATT Art. III:1, GATS Art. XVII - provided specific commitments were made), as well as the general obligations to eliminate quantitative restrictions on goods (GATT Art. XI) or the market access obligations for services (GATS Art. XVI provided specific commitments were made). Accordingly, the centre of the argument concerning the WTO consistency of AI-related sanctions would be the availability of justifications.

This chapter uses the following roadmap in assessing the relationship between predatory AI policies and WTO law. First, it considers whether certain AI policies, especially those promoting "data-sharing" mechanisms between government and private AI firms, can be challenged under WTO law. Second, it considers whether sanctions against controversial AI policies are consistent with WTO law. In doing so, this chapter examines in turn: (a) whether such sanctions contravene nondiscriminatory obligations under WTO law; (b) whether "public morals" exceptions are available to such sanctions; (c) whether security exceptions are available to such sanctions; and (d) whether "international peace and security" exceptions are available to such sanctions.

\section{DISCIPLINING “DATA-SHARING” MECHANISMS: WORLD TRADE ORGANIZATION LAW AS A SWORD?}

As stated earlier, state-operated "data-sharing" mechanisms, through which a government "feeds" data to its private entities for their development of AI products, is potentially controversial for distorting fair competition. This chapter now turns to examine whether such mechanisms can constitute an actionable subsidy under the Agreement on Subsidies and Countervailing Measures (SCM Agreement).

\section{A Are "Data-Sharing" Mechanisms Subsidies?}

The general principle in determining actionable subsidies is well established. A measure constitutes an actionable subsidy if (a) it is a subsidy, (b) it is "specific" and (c) its use causes "adverse effects". ${ }^{25}$ A subsidy exists when (a) there is a financial contribution provided by a government or any public body and (b) such a financial contribution confers a benefit. ${ }^{26}$

\section{Do "Data-Sharing" Mechanisms Provide a "Financial Contribution"?}

First, the Appellate Body in US-Softwood Lumber IV (2004) observed that "the term of 'financial contribution' has a wide definition as the transfer of something of economic value". ${ }^{27}$ Scholars further argued that data is a "substantial intangible

25 Panel Report, US-Offset Act (Byrd Amendment) (2002), para. 7.106.

26 Appellate Body Report, US-Carbon Steel (India) (2014), para. 4.8; Article 1.1 of the SCM Agreement.

27 Appellate Body Report, US-Softwood Lumber IV (2004), para. 52. 
asset" 28 that can "itself be traded", 29 or alternatively be seen as capital "for value creation". $3^{30}$ In practice, data is sold by some governments for profits. ${ }^{31}$ Accordingly, the provision of data would clearly constitute a "financial contribution".

Furthermore, in determining the existence of a "financial contribution", a government conduct must fall under one of the four types of manifestations described in subparagraphs (i)-(iv) of Art. 1.1(a)(1) of the SCM Agreement. ${ }^{32}$ Most notably, Art. 1.1(a)(1)(iii) stipulates that:

[A subsidy shall be deemed to exist if ...] a government provides goods or services other than general infrastructure, or purchases goods[.]

Accordingly, a "financial contribution" falling under Art. 1.1(a)(1)(iii) exists if (a) there is a "good or service" (b) "provided" by a government and (c) the goods/services provided are "other than general infrastructure".

WTO jurisprudence appears to construe the concept "goods or services" broadly to include all non-monetary resources. In US-Softwood Lumber IV (2004), the Appellate Body ruled that Art. 1.1(a)(1)(iii) aims to prevent the circumvention of subsidy disciplines in cases of financial contributions granted in a form other than money. 33

Case law further shows that the "goods or services" requirement would be satisfied if the resource provided is non-monetary, without requiring a panel or the Appellate Body to distinguish whether the resources in question are "goods" or "services". For instance, in US-Large Civil Aircraft (2nd complaint), the Appellate Body commented that shared "scientific information" and "rights over data" are provisions of "non-monetary resources", ${ }^{34}$ without specifying whether they are goods or services. Similarly, the Appellate Body in the same dispute ruled that the grant of access to NASA employees constitutes the provision of "goods or services". 35

Turning to consider the meaning of "provides", the Appellate Body ruled that the ordinary meaning of such a term is "supply or furnish for use; make available", ${ }^{6}$ and that "provide" does not necessarily need to be gratuitous. ${ }^{37}$

A Boerding et al., "Data Ownership: A Property Rights Approach from a European Perspective" (2018) 11 Journal of Civil Law Studies 330; M Burri, "The Regulation of Data Flows through Trade Agreements" (2017) 48 Georgetown Journal of International Law 446.

29 F Casalini and JL González, "Trade and Cross-Border Data Flows" (2019) OECD Trade Policy Papers, No. 220.

30 J Sadowski, "When Data Is Capital: Datafication, Accumulation, and Extraction” (2019) 6 Big Data \& Society 1.

${ }^{31}$ See N Lindsey, "State DMVs Selling Personal Data for Millions of Dollars in Profit" (CPO Magazine, 18 September 2019), https://perma.cc/7SBW-KRF3.

32 See Appellate Body Report, US-Large Civil Aircraft (2nd complaint) (2012), para. 613.

33 Appellate Body Report, US-Softwood Lumber IV (2004), para. 64.

34 Appellate Body Report, US-Large Civil Aircraft (2nd complaint) (2012), paras 608-609.

35 Ibid., at para. 624 .

${ }^{6}$ Appellate Body Report, US-Softwood Lumber IV (2004), para. 69.

37 Appellate Body Report, US-Large Civil Aircraft (2nd complaint) (2012), para. 618. 
As for the meaning of "other than general infrastructure", the panel in EC and Certain Member States-Large Civil Aircraft (2011) defined "general infrastructure" as "[i]nfrastructure that is not provided to or for the advantage of only a single entity or limited group of entities, but rather is available to all or nearly all entities". ${ }^{8}$ The panel in the same case further held that such an assessment is stringent, involving any related factors including "the circumstances surrounding the creation of the infrastructure in question ... the recipients or beneficiaries of the infrastructure". 39

Applying the case law summarised here to the present enquiry, the following observations can be made: first, even assuming that data may not be easily categorised as "goods" or "services", the fact that data is a non-monetary resource is already sufficient to ensure that it falls under the general scope of "goods or services". ${ }^{\circ}$ Second, even if a data-sharing mechanism may involve a bilateral exchange of data between a government and its private sector, such a mechanism still involves the provision of data, as a part of such a mechanism involves the "supply or furnish" of data by a government to its private sectors. Third, such a data-"sharing" mechanism will not qualify as general infrastructure if such a mechanism is created and designed specifically for AI firms, which are usually a small number of monopolies; ${ }^{41}$ the beneficiaries are therefore quite limited. Moreover, some data is not likely to fall within the scope of so-called public information/data, whereas it is useful for AI training, for example, medical records and ID photos. If these kinds of data are shared, the data-sharing mechanism also cannot be justified as "general infrastructure". Accordingly, it is likely that a "data-sharing" AI policy will constitute a "financial contribution" that falls within the scope of Art. 1.1(a)(1)(iii) of the SCM Agreement.

\section{Does the Financial Contribution Confer a Benefit?}

Case law stipulates that the conferral of benefit "should be determined by assessing whether the recipient has received a 'financial contribution' on terms more favourable than those available to the recipient in the market". ${ }^{2}$

Turning to the present issue of data-sharing mechanisms, note that a government operating a data-sharing mechanism is highly likely to have access to a larger pool of data than private enterprises can obtain by themselves under market conditions. Furthermore, certain governments may have access to confidential data that they have extracted through state power. Accordingly, the provision of such a data pool

$3^{8}$ Panel Report, EC and Certain Member States-Large Civil Aircraft (2011), para. 7.1036.

39 Ibid., at para. 7.1039.

$4 \circ$ The panel in US-Large Civil Aircraft (2nd complaint) (Recourse to Article 21.5) (2019) ruled that patents and right to data cannot be treated as "goods" within the meaning of Article 1.1(a)(1)(iii) since they are intangible (para. 8.832); such a ruling was rejected in the appeal (paras 5.70-5.77).

${ }^{4}$ This is because of the high-tech nature of the AI industry and economies of scale.

42 Appellate Body Report, Canada-Renewable Energy (2013), para. 5.163; see also Appellate Body Report, Canada-Aircraft (1999), para. 157. 
can confer the recipients crucial "raw materials" that cannot be easily obtained, and thereby confers them a stronger position in the market. Accordingly, such a financial contribution would confer a benefit under the meaning of SCM Art. 1.1(b); assuming that a granting authority is a "government or any public body", 43 a data-sharing mechanism would constitute a subsidy.

\section{B Do "Data-Sharing" Mechanisms Meet the Standard of "Specificity"?}

The examination of "specificity" largely depends on the facts of a particular case; it is difficult to make general pronunciations in abstract. However, a shared "data pool", being a highly technical mechanism, perhaps can only be meaningfully used by the $\mathrm{AI}$ industry. If this is so, then it is likely that a data-sharing mechanism would be specific to "certain enterprises" and not "broadly available and widely used throughout an economy". ${ }^{4}$

Further, considering that fact that a data-sharing platform designed for development of AI constitutes "a subsidy programme which is mainly used by certain enterprises", ${ }^{45}$ it is likely that a "data-sharing" mechanism can (at least) ${ }^{46}$ constitute de facto specificity under the meaning of SCM Art 2.1(c).

In the light of this analysis, a "data subsidy" is highly like to meet the standard of specificity pursuant to the SCM Agreement.

\section{Do "Data-Sharing" Mechanisms Have Adverse Effects?}

An examination of the adverse effects of a subsidy largely depends on the specific facts of an actual case; it is difficult to make general pronouncements concerning "data-sharing" mechanisms in abstract. However, a "data subsidy" has the potential of reducing the cost of collecting data for "training" AI systems, thus allowing commercial firms to cut the price of their AI products for exportation. This is likely to constitute "significant price undercutting" under the meaning of SCM Art. 6.3 (c). As such, it is possible that a "data subsidy" will have adverse effects pursuant to Arts 5 (c) and 6.3 of the SCM Agreement.

Summarising these discussions, it can be concluded that an AI policy involving a "data-sharing" mechanism is likely to constitute an actionable subsidy, under the meaning of the SCM Agreement. Consequently, injured members would be entitled to impose countervailing duties against AI products (such as AI-powered robots or vehicles) that are subsidised by "data-sharing" mechanisms.

43 Such a determination would necessarily depend on the facts of actual cases.

44 Panel Report, US-Upland Cotton (2004), para. 7.1143; see also Appellate Body Report, EC and Certain Member States-Large Civil Aircraft (2011), para. 949.

45 Panel Report, EC and Certain Member States-Large Civil Aircraft (2011), para. 7.974.

$4^{6}$ In an actual case where the legislation in question is available, it is even possible that an assessment of the legislation will lead one to conclude that such a mechanism constitutes de jure specificity. 
IV DISCIPLINING ARTIFICIAL INTELLIGENCE POLICIES: WORLD TRADE ORGANIZATION RULES AS A SHIELD?

This chapter now proceeds to consider whether an AI sanction, being an import or export restriction aimed to address other members' AI policies that undermine fundamental rights or national security (such as the proposed EU export control for cyber surveillance items against Hong Kong), would be consistent with WTO law. At the outset, it should be noted that some AI sanctions may not contravene the non-discriminatory obligations under the WTO law in the first place, since AI products that "do" and "do not" undermine such values may not satisfy the "likeness test" because of different consumer habits and preferences.

\section{A Availability of a "Public Moral" Defence}

Assuming that an AI sanction does prima facie contravene WTO rules (such as MFN/NT, general elimination of quantitative restrictions or market access obligations), this chapter now proceeds to consider whether such a sanction may be justified under the "public moral exceptions", especially Art. XX(a) of the GATT 1994 and Art. XIV(a) of the GATS.

\section{Summary of Existing Case Law}

The law pertaining to public moral exceptions is well settled. Using Art. XX(a) of the GATT 1994 as an example (as the position of GATS Art. XIV(a) is similar), the invocation of such a justification involves a two-tier test: a measure must "first be provisionally justified under $[$ Art. $\mathrm{XX}(\mathrm{a})]$, before it is subsequently appraised under the chapeau of Article XX" ${ }^{47}$ In satisfying Art. XX(a), a member must demonstrate that its measure (a) was adopted or enforced ${ }^{48}$ "to protect public morals", and (b) is "necessary" to protect such public morals. ${ }^{49}$ The enquiry then proceeds to the chapeau of Art. XX, which probes whether the application of a measure constitutes "arbitrary or unjustifiable discrimination" or "disguised restriction of international trade".

It is well settled that "public morals" is defined as "standards of right and wrong conduct maintained by or on behalf of a community or nation". ${ }^{\circ}$ Panels and the

47 Appellate Body Report, EC-Seal Products (2014), para. 5.169, referring to Appellate Body Report, US-Gasoline (1996), 22.

$4^{8}$ Appellate Body Report, EC-Seal Products (2014), para. 5.168.

49 Appellate Body Report, EC-Seal Products (2014), para. 5.169, referring to Panel Report, US-Gambling (2005), para. 6.455.

50 Panel Report, US-Gambling (2005), para. 6.465. Note that US-Gambling (2005) is a case concerning Art. XIV(a) of the GATS. The interpretation in US-Gambling (2005) was subsequently adopted in the context of Article XX(a) of the GATT 1994 by the panels in China-Publications and Audiovisual Products (2009) (in para. 7.759) and EC-Seal Products (2014) (in para. 7.380). None of these interpretations was appealed. 
Appellate Body have further given a considerable degree of deference to the members to "define and apply for themselves the concept of public morals according to their own systems and scales of values". ${ }^{11}$

The constituent test of "public morals" in GATT Art. XX(a) is represented by the panel report in EC-Seal Products (2014), in which a two-tier test was prescribed to examine: ${ }^{2}$

first, whether the [public morals] concern ... indeed exists in that society; and, second, whether such concern falls within the scope of "public morals" as "defined and applied" by a regulating Member "in its territory, according to its own systems and scales of values".

With regard to the first element, the panel considered the EU measure's text, ${ }^{53}$ legislative history, ${ }^{54}$ and structure and design; it also considered (although to a limited extent) the result of a public survey. ${ }^{55}$

With regard to the second element, the panel considered the legislative history of the $\mathrm{EU}$ measure under challenge, ${ }^{56}$ the ethical/moral references concerning seal welfare in $\mathrm{EU}$ law, ${ }^{57}$ the domestic law of certain $\mathrm{EU}$ countries ${ }^{58}$ and certain recommendations from international organisations. ${ }^{59}$

\section{Availability of the Defence}

Applying the law summarised in the previous subsection to the present discussion on AI sanctions, the following observations can be made. First, concerns relating to fundamental rights or national security are very likely to exist in the sanctioner's society, and indeed perhaps in any major society in the world. Second, fundamental rights or national security are very likely to fall within the scope of "public morals" within the sanctioner's society; in practice, the sanctioner may refer to documents such as its constitutional legislations or parliamentary records to show that its concerns are genuinely held.

Accordingly, assuming that other requirements for a "public morals" defence (such as the "necessity" test and the tests under the GATT Art. XX/GATS Art. XIV chapeau) are satisfied, an AI sanction would be successfully defended under the "public morals" exceptions. In sum, it appears that the "public morals" exceptions are, perhaps in a way similar to that in EC-Seal Products (2014), capable of

$51 \quad$ Ibid., at para. 6.461. This was followed in Panel Report, EC-Seal Products (2014), para. 7.380 and confirmed in Appellate Body Report, EC-Seal Products (2014), paras 5.199-200.

52 Panel Report, EC-Seal Products (2014), para. 7.383.

53 Ibid.

54 Ibid.

55 Ibid.

${ }^{6}$ Ibid.

57 Ibid.

$5^{8}$ Ibid.

59 Ibid. 
justifying AI sanctions genuinely held to address a concern of national security or fundamental rights.

\section{B Availability of a Defence under the "Security Exception"}

This chapter now proceeds to consider whether a WTO member may seek to justify an AI sanction relating to the protection of national security of fundamental rights under the "security exception", especially Art. XXI(b)(iii) of the GATT 1994 or Art. XIV bis of the GATS.

\section{Summary of Existing Case Law}

The panel report in Russia-Traffic in Transit (2019) ${ }^{60}$ is currently the leading case law concerning security exceptions. In essence, it ruled (in the context of Art. XXI(b) (iii) of the GATT 1994) that (a) in general, it is left to every member to define, on its own subjective standards, what it considers to be its essential security interests, ${ }^{61}$ although the exercise of such a liberty must be subject to the "obligation of good faith"; 62 and (b) it is for the panels and the Appellate Body to determine objectively whether an action taken in time of an emergency in international relations is "subject to objective determination". ${ }^{3}$

Given that the subjective tests set out here are relatively easily met, it would appear that, in determining the availability of a security exception, the core of the enquiry would be the objective determination of whether there exists an "emergency in international relations" (the "subparagraph (iii) test").

In Russia-Traffic in Transit (2019), the panel went to some lengths in considering what would constitute an "emergency in international relations". For the purpose of the present discussion, it is perhaps sufficient to notice the following points. First, the panel appeared to interpret "emergency in international relations" liberally; it held that such an expression includes "war" 64 and "[a]rmed conflict ... between governmental forces and private armed groups ... (non-international armed conflict)" ${ }^{65}$

Second, the panel ruled that an "emergency in international relations" must be understood as "eliciting the same type of interests as those arising from the other matters addressed in the enumerated subparagraphs of Article XXI(b)", 66 and that such interests are "all defence and military interests, as well as maintenance of law

6o This chapter assumes that the panel report in Russia-Traffic in Transit (2019), which was not appealed by either party, represents good law.

61 Panel Report, Russia-Traffic in Transit (2019), para. 7.131.

62 Ibid., at para. 7.133 .

63 Ibid., at para. 7.77 ; also see para. 7.82 .

64 Ibid., at para. $7 \cdot 72$.

65 Ibid.

66 Ibid., at para. $7 \cdot 74$. 
and public order interests". ${ }^{6}$ According to the panel, while it is "normal to expect that Members will ... encounter political or economic conflicts with other Members or states", 68 such conflicts "will not be "emergencies in international relations ... unless they give rise to defence and military interests, or maintenance of law and public order interests". ${ }^{9}$

Third, the panel suggested a definition for the expression "emergency in international relations", which must be reproduced in full:

An emergency in international relations would, therefore, appear to refer generally to a situation of armed conflict, or of latent armed conflict, or of heightened tension or crisis, or of general instability engulfing or surrounding a state. Such situations give rise to particular types of interests for the Member in question, i.e. defence or military interests, or maintenance of law and public order interests. ${ }^{70}$

Summarising this, it appears that the subparagraph (iii) test involves a twopronged examination ${ }^{71}$ in determining whether an "emergency in international relations" exists, namely: (a) whether there exists a "situation" of conflict, tension or crisis; and (b) whether such a "situation" gives rise to interests of "defence or military interests, or maintenance of law and public order interests". ${ }^{72}$

With regard to element (a), case law seems to require that although a "situation" needs to have some degree of seriousness (recall that the panel used the expressions "heightened tension" and "general instability" in the paragraph cited earlier), ${ }^{73}$ such a "situation" does not necessarily need to involve armed conflict ${ }^{74}$ or international conflict. With regard to element (b), recall that the expression "public order" was interpreted in the jurisprudence relating to Art. XIV(a) of the GATS to include a broad range of interests, such as the prevention of gambling.

Returning to the application of the law pertaining to the determination of "emergency in international relations", the panel report in Russia-Traffic in Transit (2019) cited approvingly the following headings of evidence adduced by Russia, and considered them "sufficient": 75

(a) the time-period in which it arose and continues to exist, (b) that the situation involves Ukraine, (c) that it affects the security of Russia's border with Ukraine in

68 Ibid.

68 Ibid., at para. $7 \cdot 75$.

69 Ibid.

70 Ibid., at para. $7 \cdot 76$.

$7^{1}$ However, note the somewhat cautious language used in the panel report: "An emergency in international relations would, therefore, appear to refer generally” (para. 7.76).

$7^{2}$ It appears that Russia-Traffic in Transit (2019) considers this to be a closed list: paras 7.74 and 7.76.

73 Panel Report, Russia-Traffic in Transit (2019), at para. 7.76.

74 Recall that the panel in Russia-Traffic in Transit (2019) ruled that "latent armed conflict, or of heightened tension or crisis, or of general instability engulfing or surrounding a state" would constitute "emergency in international relations".

75 Panel Report, Russia-Traffic in Transit (2019), at para. 7.119. 
various ways, (d) that it has resulted in other countries imposing sanctions against Russia, and (e) that the situation in question is publicly known. ${ }^{76}$

In considering such evidence, the panel referred to at least two resolutions of the UN General Assembly (UNGA), one of which "ma[de] explicit reference to the Geneva Conventions of 1949", 77 as well as several Russian domestic decrees.

Summarising this, it can be concluded that, in examining the existence of an "emergency in international relations", it is "not relevant" 78 for a panel or the Appellate Body to determine which actor bears international responsibility for the "situation", or how the "situation" should be "characterize[d] ... under international law in general". ${ }^{79}$ Instead, a panel or the Appellate Body needs to be persuaded as to the existence of a "situation" (or "element (a)" identified earlier); in doing so, it may consider the following evidence:

(a) whether the international relations in question have "deteriorated to such a degree" that they have become "a matter of concern to the international community"

(b) whether the "situation" was "recognized internationally" or "publicly known" $8 \circ$

(c) whether the "situation" "continued to exist" ${ }^{81}$ for some period

(d) whether other countries have imposed sanctions or countersanctions in connection with this "situation".

\section{Availability of the Defence}

In applying this jurisprudence to the current question of AI sanctions, it appears that sanctions for the protection of fundamental rights or for the protection of national security will satisfy the requirement of "emergency in international relations", provided the "situations" involved have the required degree of seriousness.

The determination of the degree of "seriousness" largely depends on the facts of particular cases. Nevertheless, using as an example the EU's potential ban on China's "access to technologies used to violate basic rights" due to the instabilities in Hong Kong, it would appear that the Hong Kong "situation”, which involves worldwide controversies with trade powers such as Australia, Canada, China, the EU, New Zealand, the UK and the USA, is likely to have the required degree of "heightened tension or crisis" and seriousness to satisfy element (a) of the "subparagraph (iii) test”.

\footnotetext{
$7^{6}$ Ibid., at para. 7.119 .

77 Ibid., at footnote 204 .

$7^{8}$ Ibid., at para. 7.121.

79 Ibid.

8o Ibid., at para. 7.119.

81 Ibid.
} 
Turning to element (b) of the subparagraph (iii) test, it is obvious that a "situation" concerning fundamental rights, such as the situation in Hong Kong, would (at least) give rise to interests in public order and possibly security interests. This is especially so when considering the close relationship (elaborated in subsection 1 of Section IV) between the fundamental rights of individual citizens, on the one hand, and international peace and security, on the other. Moreover, a "situation" concerning national security (such as spying) would clearly give rise to interests of defence, military and public order, consequently satisfying element (b) of the test.

As stated earlier, other requirements under Art. XXI(b)(iii) of the GATT 1994 or Art. XIV bis of the GATS are, under the current case law, subjective tests that do not present difficult hurdles to an invoking WTO member (although subject to the "obligation of good faith" requirement). ${ }^{82}$ Assuming that such tests are satisfied, it would appear that if an AI sanction serves the purpose of protecting national security or fundamental rights protection, such a sanction will be eligible for the "security exception" justification.

\section{Availability of a Defence under the "International Peace and Security" Exceptions}

It is also possible that an AI sanction can be justified under the "international peace and security" exceptions, especially Art. XXI(c) of the GATT 1994 and Art. XIV bis (c) of the GATS, both of which allow a member to justify "any action in pursuance of its obligations under the United Nations Charter for the maintenance of international peace and security". Again, the EU's proposed export control mechanisms on cyber surveillance items against China and Hong Kong can serve as an example.

The exact ambit of GATT Art. XXI(c) and GATS Art. XIV bis(c) remain uncertain at present, since none of the two provisions have been invoked before any WTO or GATT panel so far. However, using GATT Art. XXI(c) as an example, it appears that the text of this provision entails the following constituent tests: (a) the measure is imposed “in pursuance of" (b) “[the invoking member's] obligations under the United Nations Charter", (c) "for the maintenance of international peace and security".

Moreover, the broad expression "any action", read together with the lack of any "chapeau" similar to that in GATT Art. XX, seems to indicate that Art. XXI(c) entails less stringent tests than those under Art. XX. Nevertheless, the "obligation of good faith" requirement, ${ }^{83}$ which was first introduced to eliminate members' "re-label [ling of] trade interests" as "essential security interests" under GATT Art. XXI(b)(iii), might play a similar role in preventing the abuse of Art. XXI(c) justifications.

\footnotetext{
82 Panel Report, Russia-Traffic in Transit (2019), para. 7.133.

83 Ibid.
} 


\section{1 "For the Maintenance of International Peace and Security"}

A close examination of the Charter of the United Nations (UN Charter) and the ICCPR shows that it is a well-recognised principle of international law that the protection of fundamental rights for individuals also serves the purpose of maintaining international peace and security. To start with, recall that the preamble of the UN Charter provides, inter alia, that:

We the peoples of the United Nations determined ... to reaffirm faith in fundamental human rights, in the dignity and worth of the human person, in the equal rights of men and women[.]

Art. 55(c) of the UN Charter provides that:

With a view to the creation of conditions of stability and well-being which are necessary for peaceful and friendly relations among nations ... the United Nations shall promote ... universal respect for, and observance of, human rights and fundamental freedoms for all[.]

A collective reading of the UN Charter's preamble and Art. 55(c), especially the expression "with a view" in Art. 55, shows that the promotion of universal human rights and fundamental freedoms does serve for the maintenance of "peaceful ... relations among nations". Further, Art. 1.3 of the UN Charter states that "promoting and encouraging respect for human rights and for fundamental freedoms" is one of the purposes of the UN. ${ }^{84}$

In addition, the preamble of the ICCPR provides, inter alia, that:

The States Parties ... [c]onsider that, in accordance with the principles proclaimed in the Charter of the United Nations, recognition of the inherent dignity and of the equal and inalienable rights of all members of the human family is the foundation of freedom, justice and peace in the world[.]

[The States Parties recognise that] the ideal of free human beings enjoying civil and political freedom and freedom from fear and want can only be achieved if conditions are created whereby everyone may enjoy his [sic] civil and political rights[.]

These provisions reinforce a close causal relationship between the protection of the rights of "all members of the human family" and the achievement of international peace. The expression "in accordance with the principles proclaimed in the [UN] Charter" further confirms the close relationship between the obligations under the ICCPR and the UN Charter. Summarising this, it would appear that

84 See also K Kenny, "Fulfilling the Promise of the UN Charter: Transformative Integration of Human Rights" (1999) 10 Irish Studies in International Affairs 44 (arguing that international conflicts in the 199 os confirmed that human rights violations could lead to the escalation of international conflict, thus the promotion of "respect for human rights" is crucial for the UN's purpose of "the maintenance of international peace and security"). 
the policy aim of protecting fundamental rights is likely to fall within the scope of "for the maintenance of international peace and security".

\section{2 "Obligations under the UN Charter"}

Turning to examine whether the protection of fundamental rights for individuals is an "obligation" under the UN Charter, ${ }^{85}$ one could again be assisted by the earliercited UN Charter and ICCPR provisions to find a positive answer to such an enquiry. Further, the preamble of the ICCPR unequivocally recognises an "obligation of States under the [UN Charter] to promote universal respect for, and observance of, human rights and freedoms"; this confirms that the protection of fundamental rights is a Charter obligation.

\section{3 "In Pursuance of ..."}

Finally, turning to examine whether an AI sanction imposed to protect fundamental rights can satisfy the "in pursuance of" element of such a policy aim, it is perhaps prudent to say that such a determination should only be made in the context of the actual cases. However, note that the term "pursuance" is defined under the Shorter Oxford Dictionary as (inter alia) "[t]he action of trying to attain or accomplish something", and nothing (in the context, the objective and purpose, etc.) seems to indicate that the ordinary meaning of such a term should depart from its dictionary meaning. As "trying to ..." clearly denotes a much weaker causal link than "relating to", "necessary to" or "essential to", it would appear that the "in pursuance of" element would, in practice, be relatively easy to satisfy.

\section{Availability of the Defence}

As the discussions in subsection C of Section IV demonstrate, it is possible for an AI sanction imposed to protect fundamental rights to be justified under the "international peace and security" exceptions, especially Art. XXI(c) of the GATT 1994 and Art. XIV bis of the GATS. In particular, an examination of the UN Charter and the ICCPR provisions can show that the protection of fundamental rights does satisfy the "for the maintenance of international peace and security" requirement. Further, the protection of fundamental rights is also an obligation under the UN Charter. Whether an AI sanction can satisfy the "in pursuance of" requirement necessarily depends on the actual circumstances of a case, but the ordinary meaning of "in pursuance of" does not seem to demand a test as stringent as, for example, the

85 It is obvious that the general "maintenance of international peace and security" is an UN Charter obligation. For example, Art. 43(1) of the Charter provides that "All Members ... in order to contribute to the maintenance of international peace and security, undertake to make available to the Security Council, on its call". 
"necessary to" test under "general exceptions". Accordingly, it is likely that an AI sanction imposed to protect fundamental rights can be justified under the "international peace and security" exceptions.

\section{CONCLUSION}

AI technologies have brought to humanity benefits and challenges. However, some AI products may be used to threaten non-trade values including fundamental rights and national security. ${ }^{86}$ This is especially so when a trade power pursues controversial AI policies, such as developing AI systems through means that undermine fundamental rights or national security, or using AI systems for purposes of diminishing such values.

AI policies can become controversial among the international community if they (a) undermine fundamental rights, and by doing so threaten international peace and security; (b) threaten national security; and (c) raise fair competition concerns by allowing certain AI developers an unfair advantage under "data-sharing" mechanisms in accessing data to "train" their AI. Suggestions have been made for the international community to develop new disciplines in ensuring that AI technologies are used for the benefit of humanity. Yet at present, economic sanctions taken by trade powers are currently the main deterrence against the adoption of controversial AI policies.

In this chapter, it is argued that WTO law can provide some assistance in controlling controversial AI policies. First, AI policies that promote "data-sharing" mechanisms between government and private AI firms can be challenged as actionable subsidies which transfer data as "raw materials" to the private sector for the latter's development of AI products.

Second, economic sanctions against WTO members for controversial AI policies, if genuinely held to combat threats to fundamental rights or national security, are likely to be consistent with WTO law: accordingly, WTO law allows liberty for the international community to promote fundamental rights and national security by sanctioning the controversial AI policies that undermine such values. Specifically, some AI sanctions may not contravene non-discriminatory obligations under WTO law, since there might be no "likeness" between AI products that "do" and "do not" attract controversies (such as between mobile "apps" that collect data for racial profiling and those that do not). Assuming that AI sanctions are prima facie inconsistent with WTO rules on trade liberalisation, they may be justified under "public morals exceptions", "security exceptions" and/or "international peace and security" exceptions or under the GATT 1994 and/or the GATS.

It might be asked whether the WTO law, especially the various exceptions discussed here, can be used to harbour protectionist measures under the guise of 
fundamental rights or national security concerns. This is unlikely to be so. First, a member may find it difficult to argue that a protectionist measure does not contravene WTO principles of non-discrimination, since the products involved will be "like". Second, a member would also face difficulties in invoking the "public morals" defence for a protectionist measure, since doing so would involve the stringent "necessity" test and the tests under GATT Art. XX/GATS Art. XIV chapeau. Third, a protectionist measure is unlikely to be defended under security exceptions: as Russia-Traffic in Transit (2019) shows, such a measure would face difficulties in satisfying the "emergency in international relations" requirement and the "good faith" requirement.

Finally, a protectionist measure also cannot be defended under the "international peace and security" exceptions, since it is difficult to establish how a protectionist measure could contribute to the maintenance of international peace and security.

Accordingly, although WTO rules cannot be seen as a "magic pill" that instantly heals the deep divisions of humankind that were perhaps ultimately caused by ideological differences, one should be confident in their contribution to non-trade values such as security and fundamental rights. 